\title{
Field enhanced bacterial sample stacking in isotachophoresis using wide-bore capillaries
}

\author{
Farid Oukacine $^{\mathrm{a}, \mathrm{b}}$, Joselito P. Quirino ${ }^{\mathrm{a}, \mathrm{c}}$, Delphine Destoumieux-Garzón ${ }^{\mathrm{d}}$, Hervé Cottet ${ }^{\mathrm{a}, \text { * }}$
}

\begin{abstract}
a Institut des Biomolécules Max Mousseron (UMR 5247 CNRS, Université de Montpellier 1, Université de Montpellier 2), place Eugène Bataillon CC 1706, 34095 Montpellier Cedex 5, France

${ }^{\mathrm{b}}$ COLCOM SARL, Cap Alpha Avenue de l'Europe, Clapiers 34940 Montpellier, France

${ }^{c}$ Australian Centre for Research on Separation Science, School of Chemistry, University of Tasmania, Hobart 7001, Australia

d Laboratoire Ecologie des Systèmes Marins Côtiers (UMR 5119 CNRS, Université de Montpellier 2, IRD, Ifremer and Université Montpellier 1), 34095 Montpellier, France
\end{abstract}

*: Corresponding author : Hervé Cottet, Tel.: +33 467143427 ; fax: +33 467631046 ;

email address : hcottet@univ-montp2.fr

\begin{abstract}
:
The isotachophoretic analysis of different bacterial strains was studied using capillaries with different internal diameters from 50 to $250 \mu \mathrm{m}$. Several injection modes were investigated and compared in order to improve the limit of detection of bacteria by capillary isotachophoresis. A system suitability test obtained from the separation voltage was developed to ensure reliable results. As expected, the use of wider bore capillaries improved the analytical sensitivity of the isotachophoretic method when compared to the $50 \mu \mathrm{m}$ capillary. With the optimized conditions, the isotachophoretic method presented in this work allows the quantification of Erwinia carotovora (Gram negative bacteria) with a limit of detection as low as $\sim 3000$ cells $\mathrm{mL}^{-1}$. The proposed methodology does not require any additive in the electrolyte such a fluorescent or chromophoric dye to reach these limits of detection.
\end{abstract}

\section{Highlights}

Improvement of the limit of detection of bacteria in UV capillary isotachophoresis. Use of wider bore capillaries with internal diameters from 50 to $250 \mu \mathrm{m}$. Development of a system suitability test to ensure reliable results. Limit of detection as low as 3000 cells $\mathrm{mL}^{-1}$ on $200 \mu \mathrm{m}$ i.d. capillary.

Keywords: Capillary zone electrophoresis ; Isotachophoresis ; Bacteria ; Electrokinetic injection ; Field-enhanced sample injection 


\section{Introduction}

The analysis of microorganisms (e.g., bacteria) is important in forensic, pharmaceutical, food and environmental sciences [1-4]. During the last decade, there has been considerable interest in analysis of bacteria by capillary electrophoresis (CE). The analysis of charged and intact microorganisms by CE was initially proposed by Hjertén et al. [5] and has become an active research area in separation science. Developments in this area included various CE modes including capillary zone electrophoresis with dissolved additives [6-10], capillary isoelectric focusing [6,11-14], and capillary electrochromatography [15]. The control of the injected microbial band inside the capillary was vital for the reliable analysis of these samples by $C E$. The organism aggregation behavior $[8,16-17]$, the interaction with the capillary wall [18], and the focusing mechanism [6,11-14,9-23] were studied by several groups. A challenge in analysis of bacteria by $\mathrm{CE}$ is to improve detection sensitivity that is an inherent problem in CE techniques due to the narrow inner diameter of capillaries as well as the low injection volumes. On-line concentration methods $[21,22,24]$ and the use of large inner diameter capillaries [21] are often considered. Other approaches to improve detection sensitivity of bacteria by CE are based on the dynamic modification of bacterial membranes by a chromophoric surfactant [25], fluorescent surfactant [23] or the use of a fluorescent dye [26].

Recently, we have developed a new analytical methodology that allows the focusing and the mobilization of bacteria by capillary isotachophoresis (CITP) [27]. Reliable quantitation of bacteria that was obtained using $13.6 \mathrm{mM}$ TRIS / $150 \mathrm{mM}$ boric acid $(\mathrm{pH} 7.94)$ as terminating electrolyte (TE) and $4.5 \mathrm{mM}$ TRIS / $50 \mathrm{mM}$ boric acid / $3.31 \mathrm{mM} \mathrm{HCl}(\mathrm{pH} 7.28)$ as leading electrolyte (LE). The borate and chloride ions acted as terminating and leading ions, respectively. These background electrolyte systems are not commonly used in isotachophoresis. Generally, the terminating ions are only in the terminating compartment and are not present in the leading compartment. However, due to the $p K_{a}$ of boric acid (9.23) [28] and the $\mathrm{pH}$ of the $\mathrm{LE}$ (7.28), the concentration of $\mathrm{B}(\mathrm{OH})_{4}^{-}$in the leading compartment is negligible. It should be noticed that more commonly used isotachophoresis buffer system can be utilized for the ITP focusing of bacteria [27]. However, it is well-known that the concentration of bacteria suspensions can change with time. Thus, due to the bacteriostatic properties of boric acid [29], the proposed ITP electrolytes can help to maintain a constant concentration of bacteria. In addition, this ITP electrolyte system produced very low electrical currents in 50 to $100 \mu \mathrm{m}$ inner diameter capillaries (e.g., $3 \mu \mathrm{A}$ for a $100 \mu \mathrm{m}$ i.d. $\times 33.5 \mathrm{~cm}$ long). This allowed the application of relatively high voltages providing very short migration times, without increase of the equilibrium temperature or of the bacteria lysis.

By simultaneous electrokinetic and hydrodynamic injection (SEHI) (-15 kV and 17 mbar for 8 min) of bacteria prepared in 10-times diluted TE matrix, 500-fold improvement of sensitivity was obtained compared to regular hydrodynamic injection [30]. Dilution of the sample lowered the conductivity creating field enhanced or amplified sample injection conditions (FASI). A limit of detection of $\sim 2 \times 10^{4}$ cells $\mathrm{mL}^{-1}$ was obtained for Enterobacter cloacae (signal to noise $=3$ ) on a $50 \mu \mathrm{m}$ i.d. capillary. The analysis of bacteria in river and natural waters was demonstrated with SEHI-FASI-ITP method in combination with sample filtration [30].

In this work, capillaries with larger internal diameters (up to $250 \mu \mathrm{m}$ ) are used to further improve the limits of detection of bacteria by ITP using different injection modes. System suitability requirements for reliable analysis are introduced and the limits of detection are determined for different capillary i.d.. 


\section{Experimental}

\subsection{Reagents and materials}

Boric acid 99.999\%, TRIS 99.9\%, hydrochloric acid 99.999\%, and hydroxypropyl cellulose (weight average molar mass $M_{w} 10^{5} \mathrm{~g} \mathrm{~mol}^{-1}$ ) were obtained from Aldrich (Steinheim, Germany). Deionized water was purified with a Milli-Q system from Millipore (Molsheim, France). Stock solutions of boric acid, TRIS, and $\mathrm{HCl}$ were prepared with purified water. Leading (4.5 mM TRIS / $50 \mathrm{mM}$ boric acid / $3.31 \mathrm{mM} \mathrm{HCl}(\mathrm{pH} 7.28))$ and terminating (13.6 $\mathrm{mM}$ TRIS / $150 \mathrm{mM}$ boric acid $(\mathrm{pH}$ 7.94)) electrolytes were prepared by mixing aliquots of stock solutions followed by dilution with purified water in a volumetric flask. Before use, the buffer was filterd on MF-Millipore filters with $0.45 \mu \mathrm{m}$ pore size (Millipore, Molsheim, France) to remove bacterial contamination or particles. Bacterial strains used in this study were Micrococcus luteus ATCC 4698, Staphylococcus epidermidis ATTC 12228, Proteus mirabilis ATCC 29906, as well as two strains of Enterobacter cloacae and Erwinia carotovora from the IBMC Strasbourg collection). Bacteria were cultured on Luria-Bertani agar plates from Difco Laboratories (Franklin Lakes, NJ).

\subsection{Bacterial growth conditions and sample preparation}

Fresh liquid cultures of bacteria were prepared daily by inoculating $8 \mathrm{~mL}$ of Luria Bertani liquid medium with a single colony isolated from agar plates. Cultures were incubated for $13 \mathrm{~h}$ at $37^{\circ} \mathrm{C}$ with constant agitation at $160 \mathrm{rpm}$ on a rotary platform shaker. Cultures were then centrifuged (model: SIGMA 3K12, Larborzentrifugen, Osterode, Germany) at $6000 \mathrm{rpm}$ for 5 min, at $25^{\circ} \mathrm{C}$, to get the bacteria in pellet form. The supernatant was removed carefully, and the pellet was resuspended in $8 \mathrm{~mL}$ of TE by vortexing for $1 \mathrm{~min}$. The resulting bacterial suspension was then washed twice by centrifugation ( $5 \mathrm{~min}$, at $6000 \mathrm{rpm}, 5920 \mathrm{~g}, 25^{\circ} \mathrm{C}$ ). Washed bacterial cells were finally resuspended by vortexing in $8 \mathrm{~mL}$ of TE and then stored at $4{ }^{\circ} \mathrm{C}$. Each two days, new bacteria samples are prepared to ensure the reproducibility of the experiments. The turbidity of cell suspensions was measured at $600 \mathrm{~nm}$ (model: Uvikon 860 , Kontron Instruments, Zürich, Switzerland). It was assumed that the turbidity for all bacteria strains are the same $(1 \mathrm{AU}$ at $600 \mathrm{~nm}$ using $1 \mathrm{~cm}$ pathlength cell corresponds to a cell concentration of $\sim 6 \times 10^{8}$ cell $\mathrm{mL}^{-1}$ ) [31].

\subsection{Capillary coating}

The hydroxypropyl cellulose (HPC)-coated capillaries were prepared according to published protocols [32,33]. The HPC powder $\left(M_{w} 10^{5} \mathrm{~g} \mathrm{~mol}^{-1}\right)$ was dissolved in water at room temperature to a final concentration of $5 \%(\mathrm{w} / \mathrm{w})$ and the resulting polymer solution was left overnight to eliminate bubbles. The capillary lengths used for the coating of 50 and $100 \mu \mathrm{m}$ i.d. capillaries are $67 \mathrm{~cm}$ and $100 \mathrm{~cm}$, respectively. The capillary lengths used for the coating of 200 and $250 \mu \mathrm{m}$ i.d. capillaries are $200 \mathrm{~cm}$. The capillary column was filled with the polymer solution using a syringe pump (KDS100, Holliston, U.S.) for $30 \mathrm{~min}$, and the excess of solution was removed using $\mathrm{N}_{2}$ gas at 3 bar for a $50 \mu \mathrm{m}$ i.d. capillary and 0.4 bar for a 100 , 200 and $250 \mu \mathrm{m}$ i.d. capillary. The HPC polymer layer was immobilized by heating the capillary in a GC oven (GC-14A, Shimadzu, France) at $60^{\circ} \mathrm{C}$ for $10 \mathrm{~min}$ and using a linear ramp from $60^{\circ} \mathrm{C}$ to $140^{\circ} \mathrm{C}$ at $5^{\circ} \mathrm{C} / \mathrm{min}$, and finally $140{ }^{\circ} \mathrm{C}$ for $20 \mathrm{~min}$, keeping $\mathrm{N}_{2}$ pressure at 3 bar or at 0.4 bar depending on the i.d. of the capillary. The coated capillaries were rinsed with water before use. At the end of each day, the HPC-coated capillary was flushed with water and then with air. 


\subsection{CE equipment}

CE experiments were carried out with a 3D-CE instrument (Agilent technologies system, Waldbronn, Germany) equipped with a diode array detector. Bare fused silica capillaries (50, 100,200 , and $250 \mu \mathrm{m}$ inner diameter $\times 365 \mu \mathrm{m}$ outer diameter were purchased from Composite Metal Services (Shipley, UK). Analyses were performed in hydroxypropyl cellulose (HPC)-coated capillaries. LE was composed of $4.5 \mathrm{mM}$ TRIS $+50 \mathrm{mM}$ boric acid + $3.31 \mathrm{mM} \mathrm{HCl}$. TE was composed of $13.6 \mathrm{mM}$ TRIS $+150 \mathrm{mM}$ boric acid. The $\mathrm{pH}$ values of LE and TE were 7.28 and 7.94, respectively. Detection was performed at $280 \mathrm{~nm}$. The temperature of the capillary cassette was maintained constant at $25^{\circ} \mathrm{C} .2 \mathrm{~mL}$ glass vials (Agilent technologies) were used for the electrolytes and samples. Before each run, the capillary was flushed with LE. Immediately prior to the injection, the bacteria samples were vortexed for $1.5 \mathrm{~min}$ to avoid sedimentation in the vial.

\section{Results and discussion}

\subsection{System suitability}

Usually, in the ITP analysis of bacteria on neutrally coated capillary, the capillary was first filled or conditioned with LE. The sample was injected and a constant current intensity was applied with LE and TE in the outlet and inlet vial, respectively. The sample was vortexed for $90 \mathrm{~s}$ before injection to avoid bacteria sedimentation in the vial and to ensure an even distribution of the bacteria in suspension. During the ITP experiment, the separation voltage increased linearly (in absolute value) as the leading ion was replaced by the lower mobility terminating ion inside the capillary (see trace (1) of the insert of Fig. 1, plot of voltage and time). A typical ITP result using $E$. caratovora as a test bacteria is shown in trace (1) of Fig. 1. However, in some instances, the focusing of bacteria was not achieved (see trace (2) of Fig. 1) when the separation voltage remained constant for a few minutes before the typical increase in absolute value (see trace (2) of the insert of Fig. 1, plot of voltage and time). This suggests that the ITP process should start immediately to ensure the focusing of bacteria. The profile of the voltage shown in trace (2) of the insert of Fig. 1 was observed frequently with the 200 and $250 \mu \mathrm{m}$ i.d. capillaries when a hydrodynamic injection was used.

To avoid this issue, it was found that during conditioning with LE, it was important to place at the outlet a waste vial which was half filled with LE. When the waste vial did not contain an electrolyte that touched the outlet tip of the capillary, an air bubble was introduced from the inlet end. This occurred before the liquid in the sample vial touched the inlet tip of the capillary. As a system suitability test, the separation voltage that should be similar to that found in trace (1) of the insert of Fig. 1 (plot of voltage and time) was then used for all succeeding experiments. This system suitability test was employed for all capillaries.

\subsection{Isotachophoretic analysis of bacteria with hydrodynamic injection using different inner diameter capillaries}

Fig. 2 displays an ITP analysis of test bacteria ( $E$. carotovora) using different i.d. capillaries $(50,100,200$ and $250 \mu \mathrm{m})$. Capillaries of $50 \mathrm{~cm}$ totally lengths were used and the sample was injected hydrodynamically. For all the experiments shown in Fig. 2, the concentration of the bacterial suspension $\left(\sim 2.6 \times 10^{6}\right.$ cells $\left.\mathrm{mL}^{-1}\right)$ and the injected sample length $(\sim 5 \mathrm{~cm})$ were the same. In these conditions, the injected sample volume increased with the i.d. of the capillaries, since it scales as $\sim d_{c}^{2}$, where $d_{c}$ is the capillary diameter. As described in Table 1 , compared to a $50 \mu \mathrm{m}$ capillary, the volumes of injected sample in the 250,200 , and 100 $\mu \mathrm{m}$ i.d. capillaries were 25,16 , and 4 times larger, respectively. Thus, the number of bacteria 
injected in the 250, 200, 100 and $50 \mu \mathrm{m}$ i.d. capillaries were approximately of 6500,4200 , 1000 and 260 cells, respectively. The number of injected cells is much higher when a wider bore capillary is used. However, due to the ITP focusing process, all the injected bacteria initially contained in the $5 \mathrm{~cm}$ plug length are focused in a very narrow zone of about $100 \mu \mathrm{m}$ large at the interface delimiting LE and TE [27]. In this narrow zone, the density in bacteria expressed in cells $\mu \mathrm{m}^{-2}$ remains constant whatever the capillary diameter, as given in Table 1. As a consequence, according to the Beer-Lambert's law and assuming that the linear velocity was kept constant for all capillary i.d., the bacteria peak area was expected to depend linearly on the pathlength $\left(d_{c}\right)$ of the detection window. The LOD obtained for injection sample length of $\sim 5 \mathrm{~cm}$ on $50 \mathrm{~cm}$ long capillaries with $50,100,200$ and $250 \mu \mathrm{m}$ i.d. were respectively $\sim 2 \times 10^{6}, \sim 10^{6}, \sim 5 \times 10^{5}$ and $\sim 5 \times 10^{5}$ cells $\mathrm{mL}^{-1}$ in relatively good agreement with the expectations.

\subsection{Isotachophoretic analysis of bacteria by electrokinetic injection}

The main disadvantage of hydrodynamic injection (HDI) for the CE preconcentration of bacteria is the limitation of the injected sample length. In CE, another approach to improve the LOD is to use electrokinetic injection (EKI). Electrokinetic injection (EKI) can achieve from 100 to over 100 000-fold sample preconcentrations [34-39] when combined with different stacking modes, for example electrokinetic supercharging (EKS) which is a combination of field amplification and transient ITP. The EKI of different concentrations of $E$. cloacae suspensions under normal and field amplified conditions was previously unsuccessful on $50 \mu \mathrm{m}$ i.d. hydroxypropyl cellulose (HPC)-coated capillary $(33.5 \mathrm{~cm}$ total length and $25 \mathrm{~cm}$ effective length) using injection at $-15 \mathrm{kV}$ for $6 \mathrm{~s}$ [30]. Failure of the system suitability test described in section 3.1 was most likely the reason for unsuccessful EKI instead of sample depletion in the vicinity of the capillary inlet as it was first anticipated.

In this work, different bacterial strains diluted in TE were first injected by EKI and further analyzed by ITP on a $50 \mu \mathrm{m}$ i.d. capillary. Results are shown in Fig. 3 (E. cloacae (trace (2)), $E$. carotovora (trace (3)), M. luteus (trace (4)), S. epidermidis (trace (5)), and P. mirabilis (trace (6)). A blank injection is also shown in trace (1) of Fig. 3 . The system suitability tests were all fulfilled and the focusing of the bacteria was effective for all the strains. In these conditions, the limit of detection (LOD), defined as 3 times the background noise, obtained for $E$. cloacae strain is about $7 \times 10^{6}$ cells $\mathrm{mL}^{-1}$. In comparison, for a regular hydrodynamic injection (17 mbar, $6 \mathrm{~s}$, using $33.5 \mathrm{~cm}$ capillary $\times 50 \mu \mathrm{m}$ i.d.), the LOD obtained for the same bacteria strain is approximately $10^{7}$ cells $\mathrm{mL}^{-1}$. To further improve the sensitivity of detection, $\mathrm{EKI}$ in FASI conditions was examined.

\subsection{Electrokinetic supercharging of bacteria using wide bore capillaries}

Since the analysis is performed in ITP mode, EKI in FASI conditions corresponds to electrokinetic supercharging conditions. Fig. 4 displays the isotachophoretic profiles of $E$. carotovora at $\sim 1.8 \times 10^{6}$ cells $\mathrm{mL}^{-1}$ obtained by injecting at $-15 \mathrm{kV}$ for $190 \mathrm{~s}$ in FASI condition. The bacteria sample was diluted in 10-times diluted TE. The aim of this dilution was to increase the resistivity of the bacteria sample compared to LE and, consequently, to enhance the electric field in the sample zone. Different i.d. capillaries were tested (50, 100, 200 and $250 \mu \mathrm{m})$. To keep the velocity approximately constant during the ITP process, the applied current intensity was set to values proportional to the area of the capillary cross-section (1 $\mu \mathrm{A}, 4 \mu \mathrm{A}, 16 \mu \mathrm{A}$ and $25 \mu \mathrm{A}$, respectively). Under these conditions and using $50 \mathrm{~cm}$ long capillaries, we obtained LODs of approximately $4 \times 10^{5}, 10^{5}, 5 \times 10^{4}$ and $5 \times 10^{4}$ cells $\mathrm{mL}^{-1}$ for $50,100,200$ and $250 \mu \mathrm{m}$ i.d. capillaries, respectively. These LODs are still higher than that obtained in SEHI-FASI condition on a $50 \mu \mathrm{m}$ i.d. capillary (8 min under 17 mbar and $-15 \mathrm{kV}$ ) [30]. Nevertheless, SEHI cannot be applied on large i.d. capillaries, since the time required to 
fill the capillary would be too short and the injection times would be limited to very low values. Indeed, according to the Poiseuille law, the time required to fill a capillary volume at a given pressure is inversely proportional to the square of the capillary i.d..

Finally, the best way to improve the LOD when using wide bore capillary was to decrease the applied current intensity in ITP mode after EKI in FASI conditions as demonstrated in Fig. 5 in the case of $E$. carotovora suspension at $\sim 1.5 \times 10^{6}$ cells $\mathrm{mL}^{-1}$. A $50 \mathrm{~cm}$ long capillary $\times 200$ $\mu \mathrm{m}$ i.d. was used and the sample was injected by EKI at $-15 \mathrm{kV}$ for $190 \mathrm{~s}$ in FASI condition. As shown in Fig. 5, the decrease in current intensity allows reducing the velocity of displacement of the bacterial zone. As expected, when the velocity of displacement is lower, the sharp bacterial zone stays longer in the detection detector. Thus, for the same sample and the same experimental conditions for the injection step, the peak area is $88 \mathrm{mAU} s$ when the applied current intensity is $16 \mu \mathrm{A}$ (see trace (1) of Fig. 5) versus $330 \mathrm{mAU}$ s when the applied current intensity is $4 \mu \mathrm{A}$ (see trace (4) of Fig. 5). To improve further the LOD of the bacteria by ITP, the applied current intensity was decreased down to $2 \mu \mathrm{A}$ and the injection time was increased to $380 \mathrm{~s}$ at $-15 \mathrm{kV}$. The corresponding electrophoregrams are shown in Fig. 6. For the first time, without any specific additive, a LOD of $\sim 3000$ cells $\mathrm{mL}^{-1}$ was obtained using this optimized methodology. This method can be applied for the bacteria quantification in natural water, if one assumes that the detector response is similar for all bacteria strains [31]. For that, the water sample was filtered prior to injection to physically trap the bacteria in the filter [30]. Rinsing and backflushing the filter with 10 times diluted TE allowed the recovery of bacteriain absence of ionic impurities for subsequent analysis by CITP.

\section{Conclusion}

High sensitivity bacteria analysis in CE using wide bore capillaries was described in this paper. A system suitability test using the separation voltage during the ITP analysis was proposed to confirm the success of the analysis. The use of wide bore capillaries using hydrodynamic injection allows increasing the sample volume and the number of bacteria cells injected in the capillary. However, since the cross-sectional area of the capillary also increase when a wide bore capillary is used, the improvement in sensitivity only depends linearly with the pathlength of the detection window. SEHI in large bore capillaries was not adapted due to low injection times when a pressure is applied. Finally, the best way to improve further the LOD of bacteria is to use the EKI in FASI in wide bore capillary. Using 50 $\mathrm{cm}$ long capillary $\times 200 \mu \mathrm{m}$ i.d. combined with $380 \mathrm{~s}$ injection in FASI condition and $2 \mu \mathrm{A}$ applied current intensity during the ITP analysis, LOD as low as $\sim 3000$ cells $\mathrm{mL}^{-1}$ could be obtained. This method can be easily applied for the bacteria quantification in natural water.

\section{Acknowledgements}

H.C. gratefully acknowledges the support from the Institut Universitaire de France and from the Region Languedoc-Roussillon for the fellowship "Chercheurs d'Avenir". F.O. thanks COLCOM for funding a Ph.D. fellowship. J.P.Q. thanks the University of Montpellier 2 for supporting his research stay at the University of Montpellier 2 and the Australian Research Council for a Future Fellowship (FT100100213). We also thank the ANR Dendrimat (grant reference ANR-096MAPR-0022-03). 


\section{References}

[1] D.A. Veal, D. Deere, B. Ferrari, J. Piper, P.V. Attfield, J. Immunol. Methods 243 (2000) 191.

[2] H. Shintani, A. Sakudo, G.E. McDonnel, Biocontrol Science 16 (2011) 13.

[3] M.S. Cheng, S.H. Lau, V.T. Chow, C. Toh, Env. Sci. Tech. 45 (2011) 6453.

[4] G.W. Shin, H.S. Hwang, B. Chung, G.Y. Jung, Electrophoresis 31 (2010) 2137.

[5] S. Hjertén, K. Elenbring, F. Kilár, J.L. Liao, A.J. Chen, C.J. Siebert, M.D. Zhu, J. Chromatogr. 403 (1987) 47.

[6] D.W. Armstrong, G. Schulte, J.M. Schneiderheinze, D.J. Westenberg, Anal. Chem. 71 (1999) 5465.

[7] D.W. Armstrong, J.M. Schneiderheinze, Anal. Chem. 72 (2000) 4474.

[8] J.M. Schneiderheinze, D.W. Armstrong, G. Schulte, D.J. Westenberg, FEMS Microbiology Letters 189 (2000) 39.

[9] T. Shintani, K. Yamada, M. Torimura, FEMS Microbiology Letters 210 (2002) 245.

[10] E. Klodzińska, B. Buszewski, Anal. Chem. 81 (2009) 8.

[11] K. Shimura, Electrophoresis 30 (2009) 11.

[12] M. Horká, F. Růžička, J. Horký, V. Holá, K. Slais, J. Chromatogr. B 841 (2006) 152.

[13] M. Horká, J. Horký, A. Kubesová, E. Zapletalová, K. Slais, Anal. Bioanal. Chem. 400 (2011) 3133.

[14] M. Horká, J. Horký, H. Matoušková, K. Slais, J. Chromatogr. A 1216 (2009) 1019.

[15] B. Buszewski, M. Szumski, E. Klodzińska, R. Jarmalaviciene, A. Maruska, J. Chromatogr. A 1216 (2009) 6146.

[16] D.W. Armstrong, M. Girod, L. He, M.A. Rodriguez, W. Wei, J. Zheng, E.S. Yeung, Anal. Chem. 74 (2002) 5523.

[17] J. Zheng, E.S. Yeung, Anal. Chem. 75 (2003) 818.

[18] J. Petr, O. Ryparová, J. Znaleziona, V. Maier, J. Ševčík, Electrophoresis 30 (2009) 3863.

[19] M.A. Rodriguez, A.W. Lantz, D.W. Armstrong, Anal. Chem. 78 (2006) 4759.

[20] Y. Bao, A.W. Lantz, J.A. Crank, J. Huang, D.W. Armstrong, Electrophoresis 29 (2008) 2587.

[21] J. Petr, C. Jiang, J. Sevcik, E. Tesarova, D.W. Armstrong, Electrophoresis 30 (2009) 3870.

[22] L. Yu, S.F. Li, J. Chromatogr. A 1161 (2007) 308.

[23] M. Horká, J. Horký, H. Matoušková, K. Slais, Anal. Chem. 79 (2007) 9539.

[24] Y. Shen, S.J. Berger, R.D. Smith, Anal. Chem. 72 (2000) 4603.

[25] M. Horká, F. Růžička, V. Holá, V. Kahle, D. Moravcová, K. Slais, Anal. Chem. 81 (2009) 6897.

[26] A.W. Lantz, Y. Bao, D.W. Armstrong, Anal. Chem. 79 (2007) 1720.

[27] F. Oukacine, L. Garrelly, B. Romestand, D.M. Goodall, T. Zou, H. Cottet, Anal. Chem. 83 (2011) 1571.

[28] Landolt-Börnstein. Zahlenwerte und Funktionen aus Physik-Chemie-Astronomie-Geophysik und Technik; Springer: Berlin, Germany, 1960.

[29] A.G. Crann, A.W. Myres, D.W. Green, Regul. Toxicol. Pharmacol. 26 (1997) 271.

[30] F. Oukacine, J.P. Quirino, L. Garrelly, B. Romestand, T. Zou, H. Cottet, Anal. Chem. 83 (2011) 4949.

[31] F.M. Ausubel, R. Brent, R.E. Kingston, D.D. Moore, J.G. Seidman, J.A. Smith, K. Struhl, Short Protocols in Molecular Biology, Wiley, New York 2002.

[32] Y. Shen, R.D. Smith, J. Microcol. Sep. 12 (2000) 135.

[33] Y. Shen, S.J. Berger, G.A. Anderson, R.D. Smith, Anal. Chem. 72 (2000) 2154.

[34] J. Horáková, J. Petr, V. Maier, E. Tesarová, L. Veis, D.W. Armstrong, B. Gas, J. Sevcik, Electrophoresis 28 (2007) 1540.

[35] J.P. Quirino, S. Terabe, Anal. Chem. 72 (2000) 1023.

[36] J.B. Kim, K. Otsuka, S. Terabe, J. Chromatogr. A 932 (2001) 129.

[37] M. Dawod, M.C. Breadmore, R.M. Guijt, P.R. Haddad, J. Chromatogr. A 1216 (2009) 3380.

[38] M. Dawod, D.S. Chung, J. Sep. Sci. 34 (2011) 2790.

[39] T. Hirokawa, H. Okamoto, B. Gaš. Electrophoresis 24 (2003) 498. 
Tables

Table 1. Injection parameters for a bacteria suspension of $\sim 2.6 \times 10^{6}$ cells $\mathrm{mL}^{-1}$ using capillaries with different inner diameters.

\begin{tabular}{ccccccc}
\hline i.d. $(\mu \mathrm{m})$ & HDI & $L_{i n j}(\mathrm{~cm})$ & $V_{i n j}(\mathrm{~nL})$ & $N$ & $S\left(\mu \mathrm{m}^{2}\right)$ & $\rho\left(10^{-2}\right.$ cells $\left.\mu \mathrm{m}^{-2}\right)$ \\
\hline 50 & 50 mbar, 57 s & 5.00 & 98 & 260 & 1962 & 13.21 \\
\hline 100 & 12 mbar, 59 s & 4.97 & 390 & 1000 & 7850 & 13.12 \\
\hline 200 & 36 mbar, 5 s & 5.06 & 1588 & 4200 & 31400 & 13.35 \\
\hline 250 & 23 mbar, 5 s & 5.06 & 2476 & 6500 & 49062 & 13.32 \\
\hline
\end{tabular}

i.d.: inner diameter of the capillary; HDI: hydrodynamic injection condition; $L_{i n j}$ : injected sample length; $V_{i n j}$ : injection sample volume; $N$ : number of bacteria cells injected; $S$ : crosssectional area of the capillary; $\rho$ : cell density at the focusing interface.

\section{Figures}

Figure 1. System suitability requirement based on separation voltage profile for reliable bacteria analysis by CITP. Trace (1): system suitability test passed. Trace (2): system

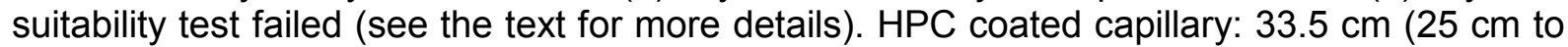
the detector) $\times 200 \mu \mathrm{m}$ i.d.. Bacteria sample: E. carotovora at $\sim 1.6 \times 10^{8}$ cells $\mathrm{mL}^{-1}$ diluted in TE. Sample injection: 10 mbar, $3 \mathrm{~s}$. Applied current intensity: $20 \mu \mathrm{A}$. For other experimental conditions see section 2.4 .

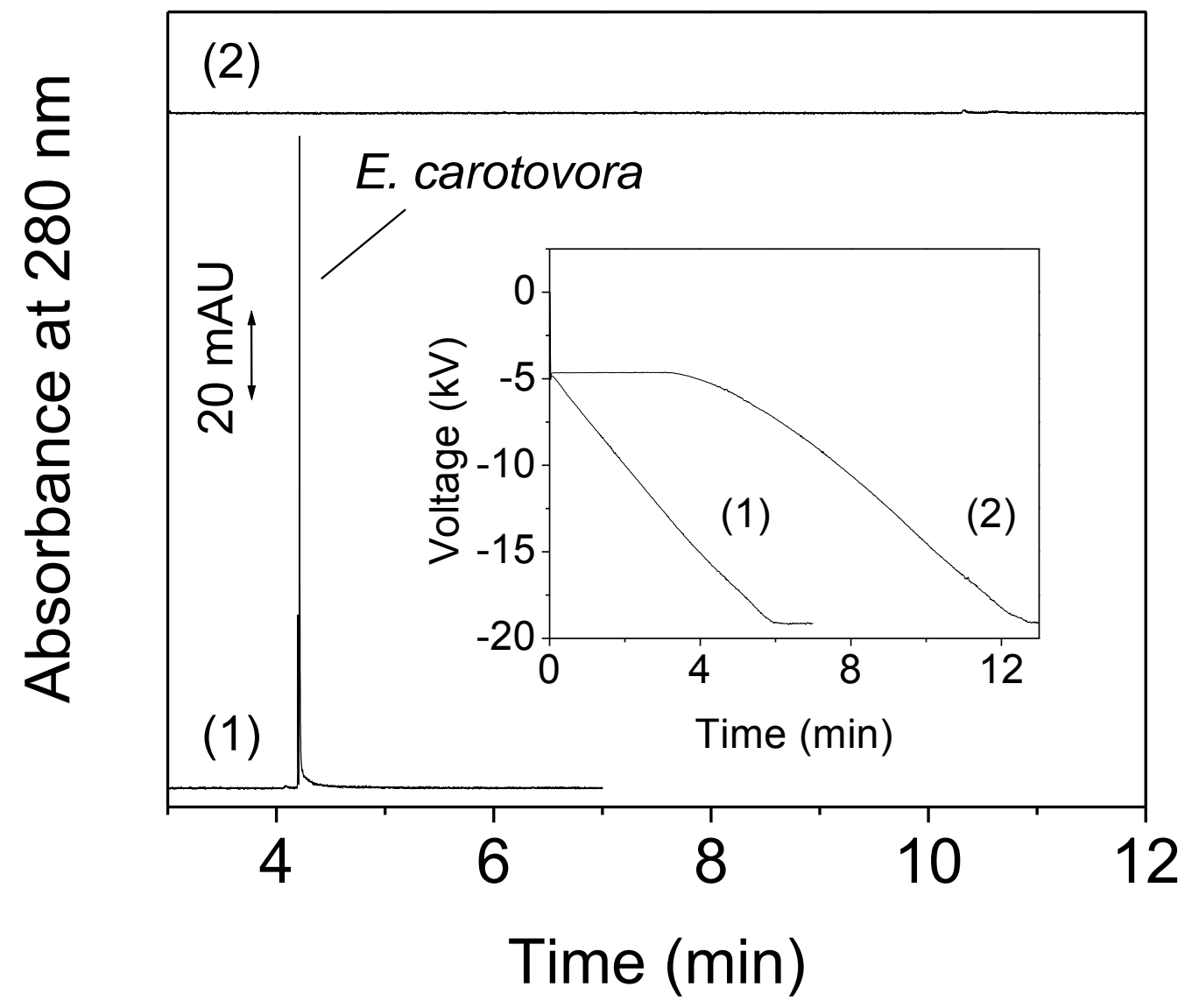


Figure 2. Hydrodynamic injection of bacteria, in ITP mode, using different inner diameter capillaries. HPC coated capillaries: $50 \mathrm{~cm}(41.5 \mathrm{~cm}$ to the detector). Inner diameters as indicated on the figure. Bacteria samples in TE: $E$. carotovora at $\sim 2.6 \times 10^{6}$ cells $\mathrm{mL}^{-1}$. Hydrodynamic injection: (1) 50 mbar, $57 \mathrm{~s}$, (2) 12 mbar, $59 \mathrm{~s}$, (3) $36 \mathrm{mbar}, 5 \mathrm{~s}$, (4) $23 \mathrm{mbar}$, $5 \mathrm{~s}$. The applied current intensity is (1) $1 \mu \mathrm{A}$, (2) $4 \mu \mathrm{A}$, (3) $16 \mu \mathrm{A}$, (4) $25 \mu \mathrm{A}$. For other experimental conditions see section 2.4 .

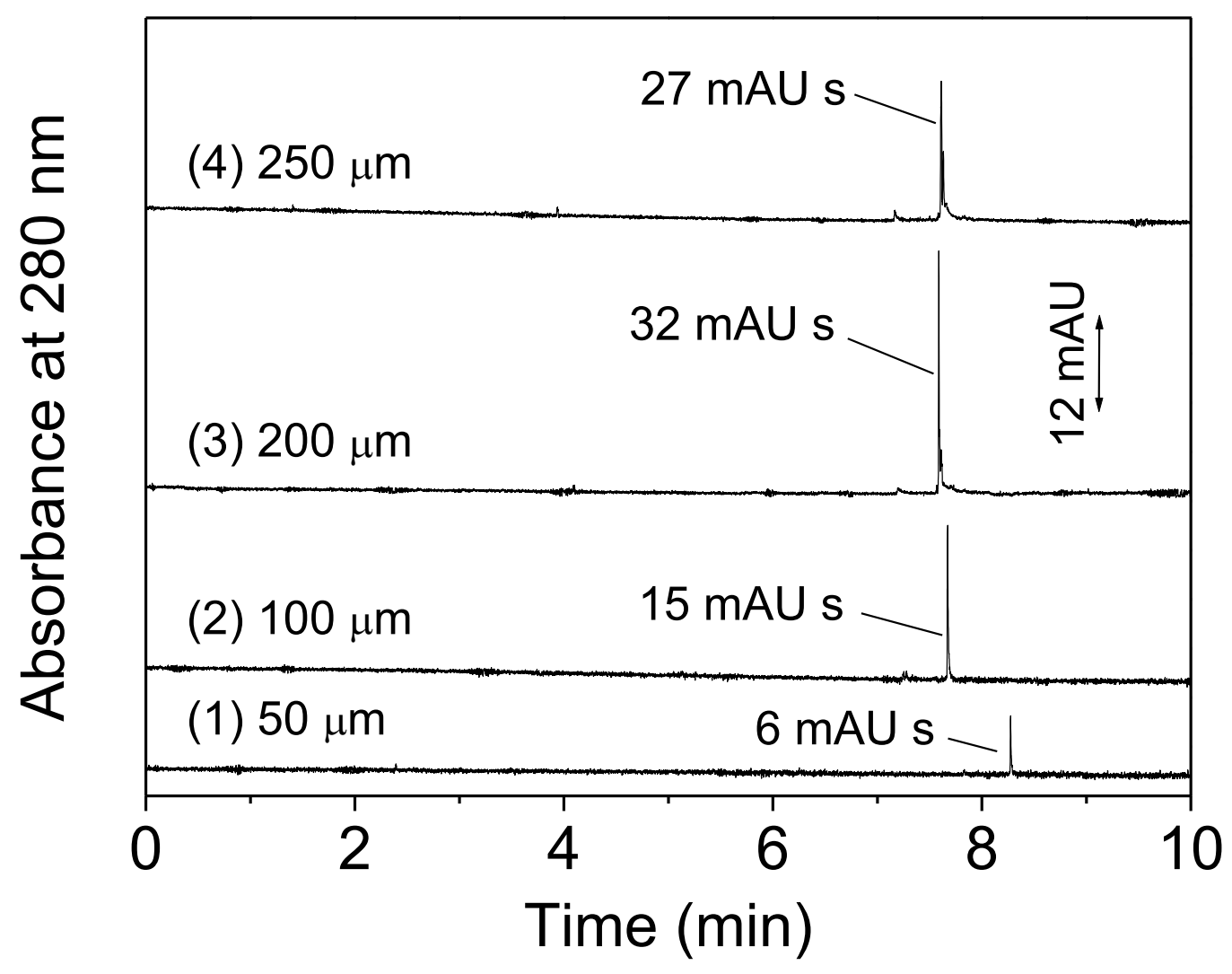


Figures 3. Electrokinetic injection of different bacteria strains by CITP. HPC coated capillary: $33.5 \mathrm{~cm}(25 \mathrm{~cm}$ to the detector $) \times 50 \mu \mathrm{m}$ i.d. Electrokinetic injection: $-15 \mathrm{kV}$ for $6 \mathrm{~s}$. Samples in TE: (1) blank, (2) E. cloacae at $\sim 8.8 \times 10^{7}$ cells $\mathrm{mL}^{-1}$, (3) E. carotovora at $\sim 9.0 \times 10^{7}$ cells $\mathrm{mL}^{-1}$, (4) M. luteus at $\sim 14.8 \times 10^{7}$ cells $\mathrm{mL}^{-1}$, (5) $\mathrm{S}$. epidermidis at $\sim 8.4 \times 10^{7}$ cells $\mathrm{mL}^{-1}$, (6) $P$. mirabilis at $\sim 10.3 \times 10^{7}$ cells $\mathrm{mL}^{-1}$. Applied current intensity: $1 \mu \mathrm{A}$. For other experimental conditions see section 2.4 .

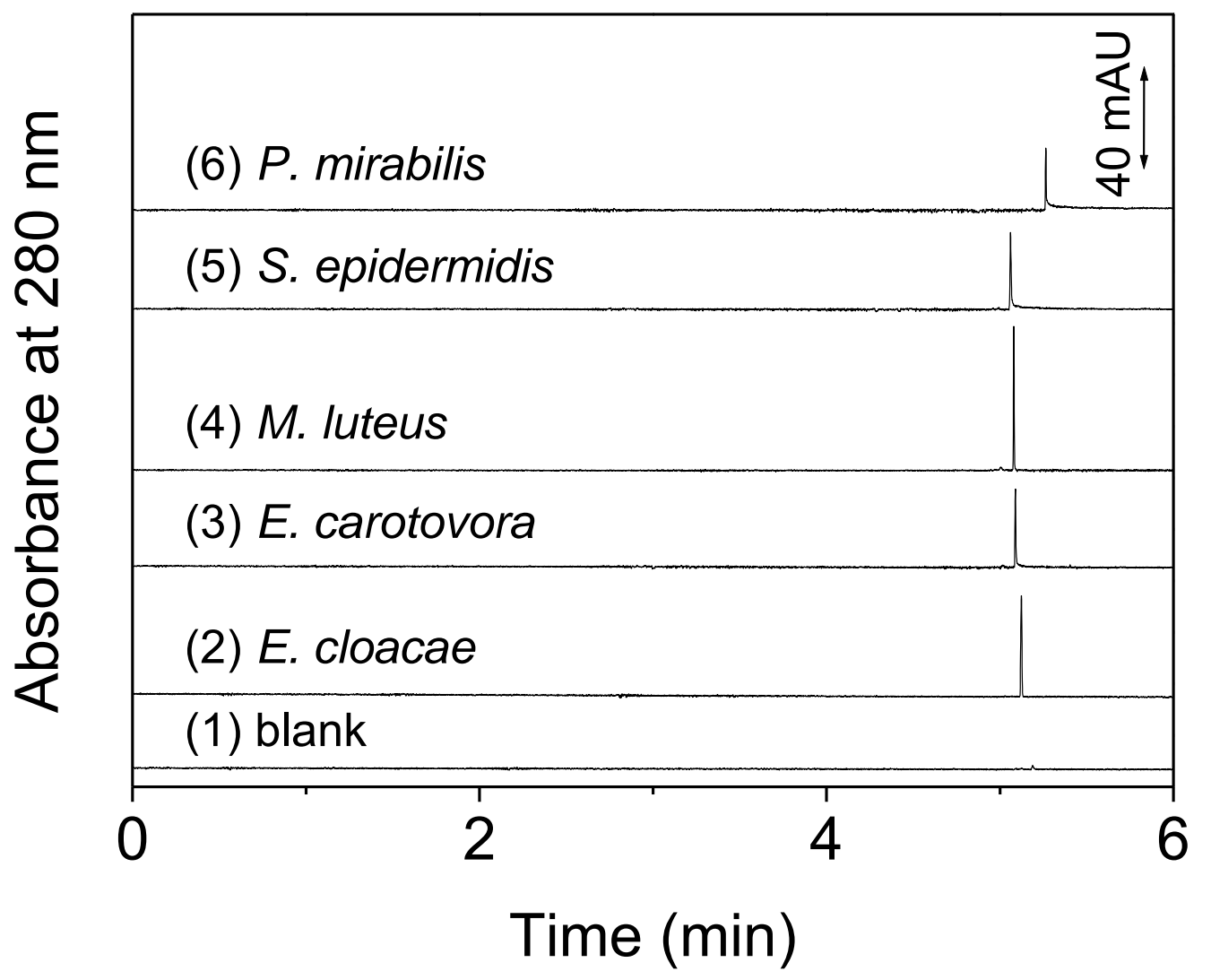


Figure 4. Electrokinetic supercharging of bacteria using different inner diameter capillaries. HPC coated capillary: $50 \mathrm{~cm}(41.5 \mathrm{~cm}$ to the detector $)$. Internal diameters as indicated on the figure. Bacteria sample: $E$. carotovora at $\sim 1.8 \times 10^{6}$ cells $\mathrm{mL}^{-1}$ in 10 -times diluted TE. Electrokinetic injection: $-15 \mathrm{kV}, 190 \mathrm{~s}$. Applied current intensity: (1) $1 \mu \mathrm{A}$, (2) $4 \mu \mathrm{A}$, (3) $16 \mu \mathrm{A}$, (4) $25 \mu \mathrm{A}$. For other experimental conditions see section 2.4.

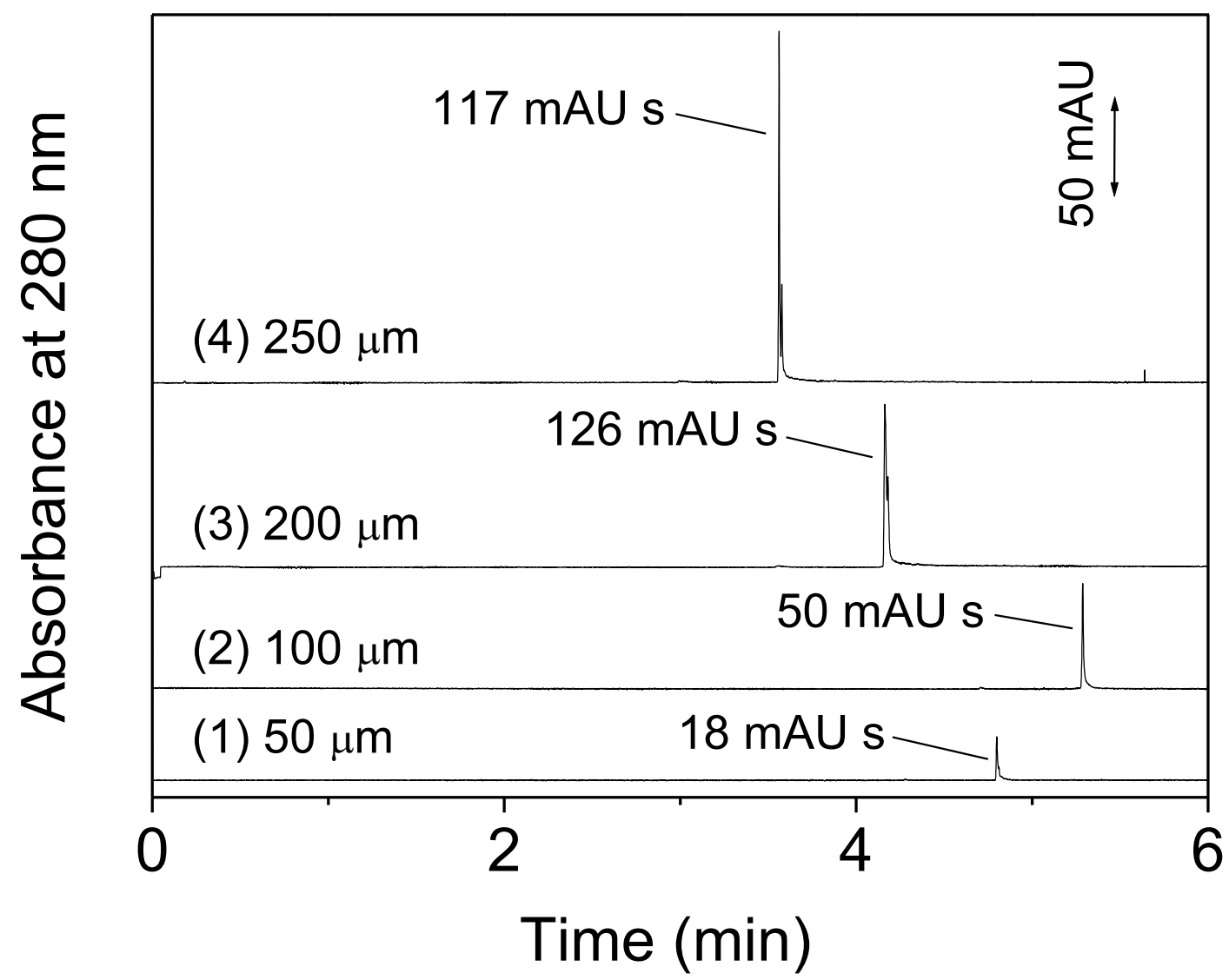


Figure 5. Effect of the applied current intensities, on the bacteria detection sensitivity, in CITP. HPC coated capillary: $50 \mathrm{~cm}(41.5 \mathrm{~cm}$ to the detector $) \times 200 \mu \mathrm{m}$ i.d.. Sample: $E$. carotovora at $\sim 1.5 \times 10^{6}$ cells $\mathrm{mL}^{-1}$ in 10 -times diluted TE. Electrokinetic injection: $-15 \mathrm{kV}, 190$ s. The applied current intensities are indicated on the figure. For other experimental conditions see section 2.4 .

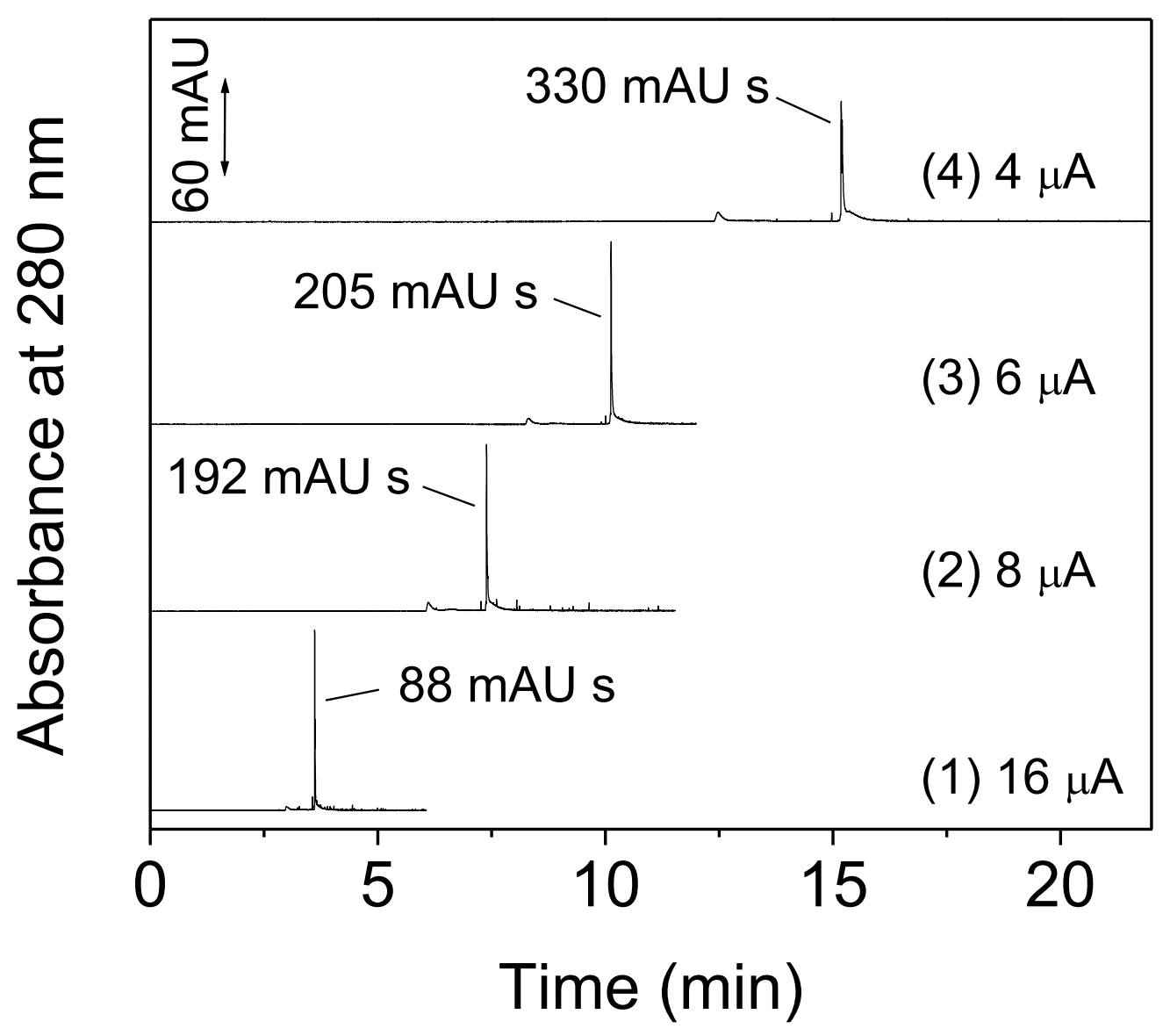


Figure 6. Electrokinetic injection using wider bore capillary with very low electrical current intensity for high bacteria sensitivity. HPC coated capillary: $50 \mathrm{~cm}(41.5 \mathrm{~cm}$ to the detector $) \times$ $200 \mu \mathrm{m}$ i.d.. Sample concentrations as indicated on the figure in 10-times diluted TE. Sample injection: $15 \mathrm{kV}, 380 \mathrm{~s}$. Applied current intensity: $2 \mu \mathrm{A}$. For other experimental conditions see Fig. 5.

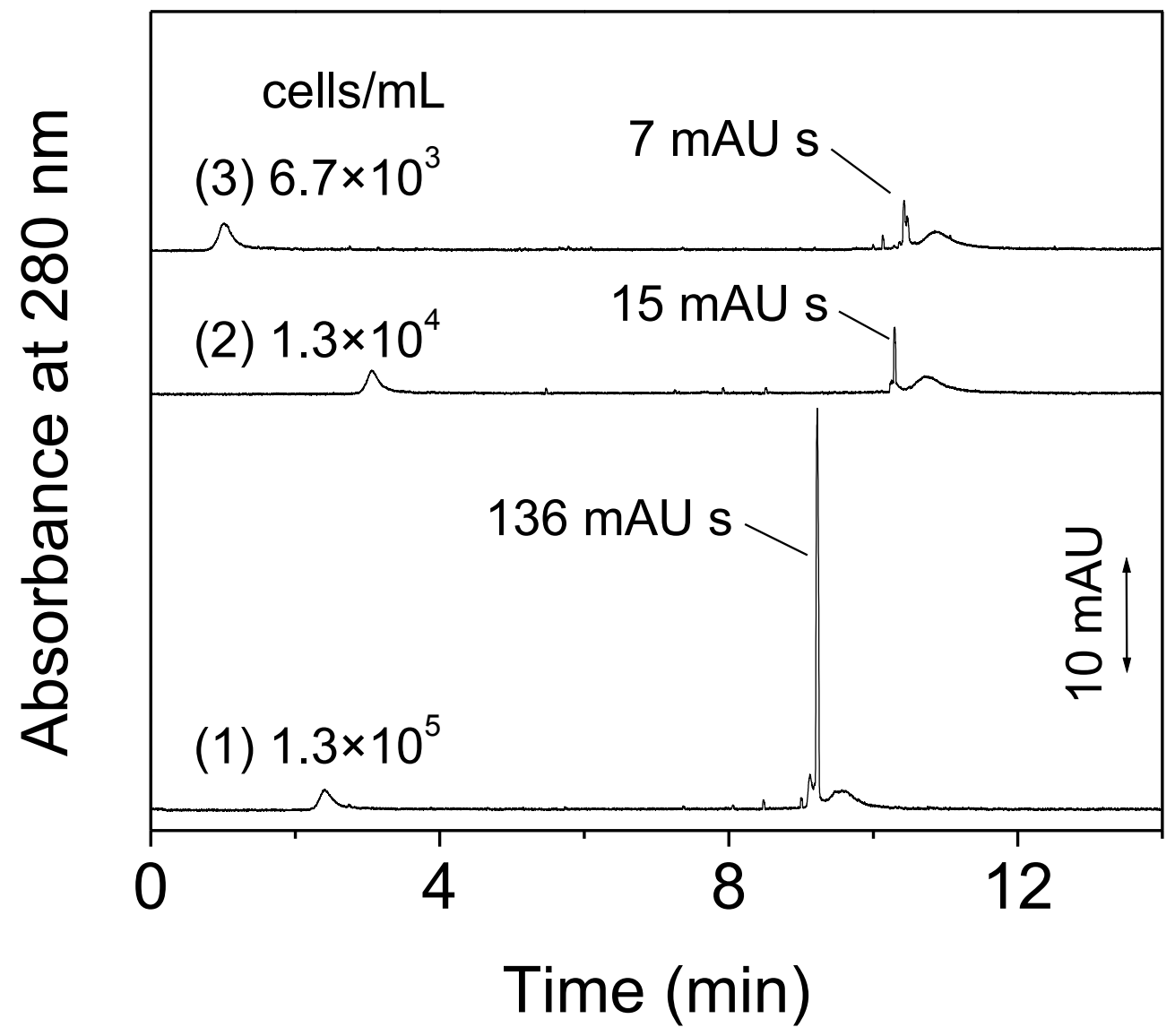

Figure 6. 